\title{
ELIT POLITIK LOKAL DALAM OTONOMI DAERAH: PERANAN PPP-KOT DALAM PEMEKARAN WILAYAH OKU TIMUR 2001-2004
}

\author{
Yunani Hasan, Farida, Alian, Aditya Rol Asmi, Aulia Novemy Dhita \\ Program Studi Pendidikan Sejarah Fakultas Keguruan dan Ilmu Pendidikan \\ Universitas Sriwijaya \\ Aliansair.fkipunsri@gmail.com
}

\begin{abstract}
Local Political Elites Regional Autonomy: The Role Of Ppp-Kot Expansion Of Oku Timur Region 2001-2004, This research will try to raise the theme of the history of regional autonomy, namely the division of the East OKU district in South Sumatra. The main problem raised in this research is the role of local political elites in the political arena when the district will separate from its parent region (OKU Regency). During the New Order period the local political elite was somewhat confined to the strong dominance of the central government to the regions. The majority of those in power in the regions are those who have been "blessed" by the central government, most of them are military officers or retirees. When the reforms began, the local political elite seemed to get a political stage back in their home region. Moreover, the legitimacy of the government through the Revision of the Reform Law makes them more free to change the state of their territory. One of the districts that was affected by the revision of the Law was East OKU. This region is separated from its parent district, OKU because of many reasons, but one of the dominant ones is the role of its local political elites.
\end{abstract}

Abstrak:Elit Politik Lokal Dalam Otonomi Daerah: Peranan Ppp-Kot Dalam Pemekaran Wilayah Oku Timur 2001-2004, Penelitian yang bertemakan sejarah ini akan coba mengangkat tema sejarah otonomi daerah yaitu pemekaran wilayah kabupaten OKU Timur di Sumatera Selatan. Permasalahan utama yang diangkat dalam penelitian ini adalah seputar peranan elit politik lokal dalam percaturan politik ketika kabupaten tersebut akan berpisah dari wilayah induknya (Kabupaten OKU). Selama masa Orde Baru elit politik lokal agak terkungkung dengan kuatnya dominasi pemerintah pusat hingga ke daerah. Mayoritas yang berkuasa didaerah merupakan mereka yang telah "direstui" oleh pemerintah pusat, sebagian besar merupakan perwira ataupun pensiunan militer. Ketika reformasi bergulir, elit politik lokal seakan mendapat panggung politik kembali didaerah asalnya. Apalagi legitimasi pemerintah lewat Revisi UU reformasi membuat mereka semakin leluasa mengubah keadaan wilayahnya. Salah satu kabupaten yang mendapat dampak dari revisi UU tersebut adalah OKU Timur. Wilayah ini berpisah dari kabupaten induknya yaitu OKU karena banyak sebab, namun salah satu yang dominan adalah peran para elit politik lokalnya.

\section{Pendahuluan}

Pada awal pelaksanaan otonomi daerah pasca reformasi, sebenarnya pemerintah juga sudah melakukan semacam kegiatan percontohan, dimana pemerintah memekarkan beberapa kabupaten agar bisa menjadi contoh pada kabupaten lain jika akan mekar pula. Namun kembali lagi pada permasalahan apakah otonomi itu berhasil atau tidak. Ekperimen ini tidaklah bersifat kimiawi seperti yang ada di laboratorium yang bisa dijadikan semacam kelinci percobaan, namun lebih dari pada itu percontohan ini 
menyangkut hajat hidup orang banyak. Salah satu kabupaten percontohan pasca reformasi adalah wilayah Muara Enim di Sumatera Selatan ${ }^{1}$ Pemilihan beberapa kabupaten termasuk Muara Enim di Sumatera Selatan itu bukan tanpa sebab, kabupaten-kabupaten itu memiliki potensi-potensi sumber daya alam yang besar, memiliki kemampuan keuangan yang memadai, serta keadaan geografis dan demografi yang turut menunjang kemandirian kabupaten itu. Seperti kabupaten Muara Enim yang terkenal karena daerah pemasok Batu bara dengan skala besar di Indonesia, disamping itu potensi perkebunan karet dan kelapa sawit yang juga memberi pemasukan yang besar bagi kabupaten itu sendiri. Maka dengan kesuksesan beberapa kabupaten percontohan ini, diharapkan daerah lain turut mempersiapkan hal yang sama, agar Otonomi daerah bukan hanya dijadikan pengalihan kekuasaan dari elit politik pusat ke daerah, namun berpengaruh pada perkembangan kabupaten itu sendiri.

Disamping itu pelaksaan undangundang tersebut juga wajib menjalankan prinsip-prinsip pembagian kewenangan berdasarkan atas asas dekonsentrasi dan desentralisasi dalam kerangka Negara Kesatuan Republik Indonesia. Daerah yang dibuat atas asas dekonsentrasi adalah berupa provinsi sedangkan asas yang mengilhami desentralisasi berupa kota dan kabupaten ${ }^{2}$

Pada masa sekarang pun jika kita kembalikan pada esensi perundangundangan yang berlaku mengenai otonomi daerah, sebenarnya juga terkait dengan pelaksanaan administratif pusat yang dilimpahkan ke daerah, karena daerah lebih dekat dengan rakyat, walaupun alasan sebenarnya lebih kepada efisiensi anggaran. Sejumlah ilmuan politik dan pemerintahan memberi alasan mengapa otonomi daerah dalam kaitan ini desentralisasi perlu dilaksanakan: (1) peningkatan efisiensi dan efektivitas penyelenggaraan pemerintahan, wahana pendidikan politik dimasyarakat daerah, (3) integrasi nasional mewujudkan demokrasi di daerah, (5) memberi peluang bagi masyarakat berkarir dibidang politik dan pemerintahan, (6) wahana masyarakat untuk berpartisipasi pada proses penyelenggaraan negara, (7) sarana mempercepat pembangunan daerah, (8) mewujudkan pemerintahan yang bersih dan berwibawa. ${ }^{3}$

Pada poin nomor 5 yaitu memberi peluang bagi masyarakat berkarir dibidang politik dan pemerintahan, perlu di pahami sebagai sarana timbulnya elitelit politik baru pasca reformasi. Seperti yang kita ketahui elit politik lokal ketika masa Orde Baru tidak terlalu bergaung jika dibandingkan dengan elit-elit politik lokal pasca Reformasi. Namun adakalanya juga elit-elit ini dijadikan sebagai "bensin pembakar" isu-isu primordial dan etnosentrisme yang berkembang dalam otonomi daerah. Isuisu ini bukan sekadar isapan jempol belaka, namun dibeberapa kasus memang terjadi. Contohnya pada penamaan kabupaten atau wilayah baru hasil pemekaran lebih condong ke ranah kesukuan daripada nama wilayah itu sendiri secara geografis. Sebenarnya adanya elit politik lokal harusnya bisa menjadi semacam jargon utama dalam memberikan pendidikan politik pada rakyat di ranah lokalnya, agar mengesampingkan kesukuan dalam rangka nasionalisme yang dikemas dalam Negara Kesatuan Republik Indonesia.

Adapun elit politik lokal yang dimaksud adalah mereka yang menduduki posisi jabatan politik di ranah lokal. Perjalanan sejarah mencatat bahwa posisi mereka sebagai elit politik lokal mengalami 'pasang naik' dan 'pasang surut' paralel dengan perubahan yang terjadi. Mereka yang pada rentang waktu tertentu mengalami pembatasan dari struktur yang ada, berubah nasibnya menjadi mengalami pemberdayaan pada kurun waktu yang lain. Demikian pula ada di antara mereka yang semula mengalami pemberdayaan berubah 
menjadi mengalami pembatasan dari struktur. Realitas pentas politik Indonesia menunjukkan, tatkala rezim otoritarian Orde Baru berkuasa, ada sekelompok elit politik lokal yang mengalami pembatasan dari struktur yang ada dan ada pula sejumlah elit politik lokal lainnya yang mengalami pemberdayaan. Tumbangnya pemerintahan Orde Baru menghasilkan kehadiran sistem politik yang bercorak demokrasi memungkinkan terjadinya perubahan pemaknaan struktur yang ada; elit politik lokal yang semula memaknai struktur sebagai pembatasan berubah menjadi pemberdayaan, dan mereka yang tadinya memaknai sebagai pemberdayaan berubah menjadi pembatasan. Tulisan ini membahas posisi elit politik lokal yang mengalami perubahan menyusul tumbangnya rezim otoritarian Orde Baru dari kaca mata strukturasi 4 .

Dalam kaitannya dengan otonomi daerah, secara ekonomis Oku Timur bisa menjadi kabupaten yang mandiri lepas dari kabupaten Induknya. Sebagai sebuah negara kesatuan, Indonesia rentan akan perpecahan karena banyaknya ego masalah pengelolaan ekonomi didaerah, walaupun terkadang isu etnosentrisme dan primordialisme itu bisa dibungkus rapi didalam masalah pengelolaan ekonomi tadi ${ }^{5}$ Maka dengan uraian inilah saya tertarik untuk mengangkat sebuah tema penelitian mengenai sejarah otonomi daerah. Dalam kaitan ini otonomi daerah yang terdapat diwilayah Oku Timur, Sumatera Selatan. Namun fokusnya terletak pada, peranan elit politik lokal dalam proses otonomi itu sendiri.

Beranjak dari uraian diatas tentang peranan sebuah elit politik lokal dalam otonomi daerah, maka harus ada peranan yang signifikan dalam proses otonomi itu sendiri. PPP-KOT yang ada di Oku Timur tidak tumbuh begitu saja dalam rangka isu-isu otonomi daerah pada waktu itu. Perlu dilihat lebih jauh apakah elit politik lokal ini memang representasi dari rakyat atau hanya sekedar tameng agar mendapat pelimpahan kekuasaan dari pusat. Elit sendiri dalam kaitan ini mereka yang punya modal-modal yang berpengaruh dalam masyarakat, entah itu modal kapital berupa uang, modal sosial ataupun modal pendidikan. Pada masa kolonial Belanda, posisi elit memang penting dalam hierarki struktur masyarakat terutama di pedesaan. Kebanyakan mungkin mereka adalah tuan tanah dengan banyak pekerja didalamnya. Namun bagaimana kaitannya dengan peranan elit tersebut ketika masa kontemporer? Adakah perbedaan dengan masa ketika Indonesia dijajah Belanda. Ketika masa Orde Baru yang sentralistik, peranan elit politik lokal memang tergerus oleh struktur, hanya mereka yang terafiliasi dengan rezim akan selamat, sedangkan sisanya yang melawan biasanya akan dengan mudah diberantas pemerintah waktu itu.

Dengan kata lain elit politik lokal pada waktu itu tidak diuntungkan oleh struktur yang ada, namun ketika rezim politik Orde Baru itu runtuh struktur yang tadi mengekang menjadi luwes akibat dikeluarkannya beberapa undangundang terkait masalah otonomi daerah. Reformasi benar-benar menjadi panggung bagi para elit politik lokal untuk "show time".

\section{Metodologi}

Artikel ini menggunakan metode sejarah yaitu meliputi Heuristik, kritik sumber, interpretasi dan historiografi. pada tahap ini, peneliti mengumpulkan data atau mencari sumber-sumber berdasarkan tujuan penelitian seperti sumber tertulis baik berupa buku, majalah, surat kabar, jurnal-jurnal. atau dokumen-dokumen lainnya yang berkaitan dengan penelitian. peneliti berusaha untuk mencari sumber-sumber yang sesuai dengan tema yang dikaji yang berkaitan dengan sejarah lokal Palembang sesuai dengan interval tahun yang diteliti. Sumber yang diperoleh dilakukan dengan 
studi kepustakaan dan wawancara kepada narasumber yang relevan.

Pada penulisan artikel ini menggunakan kritik sumber sebagai salah satu metode penelitiannya. Ada dua macam kritik, yaitu kritik ekstern dan kritik intern. Kritik ekstern untuk mencari otentitas atau keotentikan (keaslian) sumber, sedangkan kritik intern menilai apakah sumber itu memiliki kredebilitas (kebiasaan untuk dipercaya) atau tidak6. Peneliti melakukan kritik sumber seperti data-data yang ada pada sumber-sumber buku dan di bandingkan dengan sumbersumber dari majalah lokal sezaman tentang data statistik mengenai perekomian dalam interval waktu penelitian.

Pada tahapan terakhir adalah penulisan dan interpretasi. Dalam sejarah terdapat dua unsur yang penting, yaitu fakta dan penulisan atau interpretasi. Jika tidak interpretasi, maka sejarah tidak lebih merupakan kronik, yaitu urutan peristiwa. Jika tidak ada fakta, maka sejarah tidak mungkin dibangun. Peneliti melakukan interpretasi atau penafsiran atas fakta-fakta sejarah, yang terdiri dari (1) mentifact (kejiwaan), (2) sosifact (hubungan sosial), (3) artifact (benda) ${ }^{7}$. Pada bagian ini setelah melakukan proses pengumpulan data dan juga melakukan kritik terhadap sumber maka peneliti melakukan interprestasi terhadap datadata yang sudah dikumpulkan sehingga menimbulkan pemikiran baru tentang apa yang telah diteliti. Tahapan ini menentukan apakah kita mampu untuk menganalis sumber-sumber itu menjadi tulisan yang baru, dibutuhkan analisis yang mendalam sehingga tidak hanya sekedar menjadi tulisan yang dangkal

\section{Pembahasan}

\subsection{Latar Belakang Terbentukmya} Daerah Otonomi Daerah di OKU Timur Pemekaran suatu daerah mempunyai dampak positif, yaitu paling tidak telah membuka keterisolasian daerah-daerah terpencil. Faktor ini sangat penting untuk pertumbuhan ekonomi daerah dan daya tarik bagi investor untuk menanamkan modal ke daerahdaerah pemekaran. Di samping itu, pemekaran daerah juga telah membuka lapangan kerja baru bagi calon-calon PNS, pejabat dan politisi di tingkat lokal; memberikan pelayanan pendidikan dan kesehatan minimal kepada warga masyarakat setempat. Namun, dampak positif pemekaran ini menurut saya masih terlalu kecil bila dibandingkan cost ekonomi, politik dan sosial dari pemekaran daerah selama sekitar 10 tahun terakhir ini ${ }^{8}$

Dari sisi integrasi nasional, pemekaran daerah dan otonomi daerah saat ini mampu menjadi 'pilihan kebijakan' jangka pendek untuk mengatasi kegagalan Orde Baru di masa lalu dalam menciptakan pemerataan keadilan dan pembangunan Jawa-Luar Jawa. Agar solusi jangka pendek ini mampu menjadi solusi jangka menengah dan panjang, mau tidak mau, kebijakankebijakan dan implementasi otonomi daerah dan pemekarandaerah di masa datang harus berorientasi kerakyatan, didasari penelitian dan kajian yang mendalam dan menyelamatkan bangsa dan negara Indonesia (termasuk kajian mengenai penggabungan daerah).

Struktur kelembagaan dan mekanisme kerja disemua tingkat pemerintahan, khususnya Pemerintah Desa yang langsung berhubungan dengan masyarakat diarahkan untuk dapat menciptakan pemerintah yang peka terhadap perkembangan dan perubahan yang terjadi di dalam masyarakat sehingga Pemerintahan Desa selaku pembina dan pengayom bagi masyarakat dapat digerakkan untuk berpartisipasi dalam menjalankan tugas dan fungsinya, dandapat bekerjasama dengan baik. Kepala Desa dibantu oleh Perangkat Desa dan BPD, sebagai mitra Kepala Desa mempunyai kedudukan yang sejajar dengan BPD, juga sangat berperan dalam mengayomi masyarakat desa. 
Berkaitan dengan Otonomi Daerah, bagi Pemerintah Desa dimana keberadaannya berhubungan langsung dengan masyarakat dan sebagai ujung tombak pembangunan. Desa semakin dituntut kesiapannya baik dalam hal merumuskan kebijakan desa (dalam bentuk Peraturan Desa/Perdes), merencanakan pembangunan desa yang disesuaikan dengan situasi dan kondisi serta dapat memberikan pelayanan rutin kepada masyarakat.

Menurut Alexander Abe faktorfaktor yang mempengaruhi partisipasi politik masyarakat: Faktor Sosial Ekonomi, Kondisi sosial ekonomi meliputi tingkat pendapatan, tingkat pendidikan dan jumlah keluarga; Faktor Politik, Peran serta politik masyarakat didasarkan kepada politik untuk menentukan suatu produk akhir; Faktor politik meliputi: Komunikasi Politik, Komunikasi politik adalah suatu komunikasi yang mempunyai konsekuensi politik baik secara aktual maupun potensial, yang mengatur kelakuan manusia dalam keberadaan suatu konflik; Kesadaran Politik; Kesadaran politik menyangkut pengetahuan, minat dan perhatian seseorang terhadap lingkungan masyarakat dan politik. Tingkat kesadaran politik diartikan sebagai tanda bahwa warga masyarakat menaruh perhatian terhadap masalah kenegaraan dan atau pembangunan; Pengetahuan Masyarakat terhadap Proses Pengambilan Keputusan; Pengetahuan masyarakat terhadap proses pengambilan keputusan akan menentukan corak dan arah suatu keputusan yang akan diambil; Kontrol Masyarakat terhadap Kebijakan Publik, Kontrol masyarakat terhadap kebijakan publik yakni masyarakat menguasai kebijakan publik dan memiliki kewenangan untuk mengelola suatu objek kebijakan tertentu. Kontrol untuk mencegah penyalahgunaan kewenangan dalam keputusan politik, kontrol masyarakat dalam kebijakan publik adalah kekuasaaan langsung atau the power of directing 9

Kontrol ini juga mengemukakan ekspresi politik, memberikan aspirasi atau masukan tanpa intimidasi yang merupakan problem dan harapan rakyat, untuk meningkatkan kesadaran kritis dan keterampilan masyarakat melakukan analisis dan pemetaan terhadap persoalan aktual dan merumuskan agenda tuntutan mengenai pembangunan; Faktor Fisik Individu dan Lingkungan, Faktor fisik individu sebagai sumber kehidupan termasuk fasilitas sertakesediaan pelayanan umum. Faktorlingkungan adalah kesatuan ruang dansemua benda, daya, keadaan, kondisi danmakhluk hidup, yang berlangsungnyaberbagai kelompok beserta lembaga danpranatanya; Faktor Nilai Budaya, Nilai budaya politik atau civic cultural merupakan basis yang membentukdemokrasi, hakekatnya adalah politik baiketika politik maupun teknik politik. Faktornilai budaya menyangkut persepsi,pengetahuan, sikap, dan kepercayaan politik.

Dinamika politik lokal di Indonesia selalu berubah sepanjang waktu. Pada era sebelum kemerdekaan, politik lokal di Nusantara menunjukkan potret buram karena penguasa memperoleh kekuasaan dalam kerangka hukum adat yang totaliter. Akibatnya sebagian besar lapisan masyarakat hanya diakui sebagai hamba (bukan warga) yang tidak pernah menjadi subjek pembangunan semasa itu. Masyarakat dijadikan objek dari kehidupan politik yang tidak berpihak kepada mereka. Pelbagai bentuk pajak dan upeti ditarik oleh penguasa melalui aparatur represifnya yang menjadikan kondisi ekonomi masyarakat semakin terpuruk ${ }^{10}$.

Pada awalnya kabupaten OKU timur merupakan bagian dari Kabupaten OKU, Nama Kabupaten Ogan Komering Ulu diambil dari nama dua sungai besar yang melintasi dan mengalir di sepanjang wilayah kabupaten OKU, yaitu sungai 
Ogan dan Sungai Komering. Berdasarkan sejarah, sesuai dengan kesepakatan yang tertuang dalam Peraturan Daerah Kabupaten Ogan Komering Ulu Nomor 9 Tahun 1997 tanggal 20 Januari 1997, Tahun 1878 ditetapkan sebagai tahun kelahiran nama Ogan Komering Ulu. Sedangkan berdasarkan peraturan perundang-undangan, Kabupaten Ogan Komering Ulu terbentuk dengan keluarnya Undang-undang Nomor 11 Tahun 1950 tentang Pembubaran Negara Bagian Sumatera Selatan dan Peraturan Pemerintah Penganti Undang-undang Darurat Nomor 3 Tahun 1950 tentang Pembentukan Daerah Sumatera Selatan menjadi Propinsi di dalam Negara Republik Indonesia.

Selanjutnya melalui Keputusan Gubernur Sumatera Selatan Nomor GB/100/1950 tanggal 20 Maret 1950, ditetapkan batas-batas wilayah Kabupaten Ogan Komering Ulu dengan ibu kota kabupaten di Baturaja. Sejalan dengan Undang-undang Darurat Nomor 4 Tahun 1956 yang diperkuat dengan UndangUndang Republik Indonesia Nomor 28 Tahun 1959 tentang Pembentukan Daerah Tingkat II Kotapraja di Sumatera Selatan (Lembaran Negara Republik Indonesia Tahun 1959 Nomor 73. Tambahan Lembaran Negara Republik Indonesia Nomor 1821), Kabupaten Ogan Komering Ulu menjadi daerah otonom yang berhak mengatur dan mengurus rumah tangganya sendiri.

OKU Timur merupakan kabupaten hasil dari pemekaran kabupaten OKU yang beribu kota di Baturaja, Kabupaten OKU sendiri dimekarkan menjadi 3 kabupaten yaitu OKU, OKU Selatan, dan OKU Timur. masyarakat yang menghendaki pemekaran Kabupaten Ogan Komering Ulu dengan pertimbangan untuk mempersingkat rentang kendali pelaksanaan pemerintahan, meningkatkan pelayanan, kemudahan pengawasan dan meningkatkan kemampuan daerah dalam pemanfaatan sumber daya alam, serta mempercepat proses pembangunan dalam rangka percepatan tercapainya kesejahteraan masyarakat.(wawancara dengan bapak Agustian Pahrimale, sekertaris bidang program dinas pendapatan daerah OKUT)

Penyelenggaraan pemerintahan dan pelayanan masyarakat. Sebagai daerah otonom, daerah mempunyai kewenangan dan tanggung jawab menyelenggarakan kepentingan masyarakat berdasarkan prinsip-prinsip keterbukaan, partisipasi masyarakat, dan pertanggungjawaban masyarakat 11. Sesuai dengan semangat Otonomi Daerah, berdasarkan Undang-Undang Republik Indonesia Nomor 4347, pada tahun 2003 Kabupaten OKU resmi dimekarkan menjadi 3 (tiga) Kabupaten, yakni (1) Kabupaten Ogan Komering Ulu Timur (OKU TIMUR) dengan Ibukota Martapura; (2) Kabupaten Ogan Komering Ulu Selatan (OKU SELATAN) dengan Ibukota Muaradua dan (3) Kabupaten Ogan Komering Ulu (OKU) dengan Ibukota Baturaja. (http:/ / Kabupaten Ogan Komering Ulu -, diaksespada 11 September 2018)

Menyikapi hal itu, pada tanggal 25 Mei Tahun 2001 Pemerintah Kabupaten Ogan Komering Ulu melalui surat Nomor 136/II/2001 mengusulkan rencana pemekaran Kabupaten Ogan Komering Ulu kepada DPRD Kabupaten Ogan Komering Ulu. Selanjutnya DPRD Kabupaten Ogan Komering Ulu menanggapi dengan mengeluarkan surat keputusan DPRD Kabupaten Ogan Komering Ulu Nomor 33 Tahun 2001, tanggal 13 Juli 2001 yang isinya menyetujui rencana pemekaran wilayah Kabupaten Ogan Komering Ulu. Melalui surat keputusan Bupati Ogan Komering Ulu Nomor : 125/10.A/SK/2001 dibentuk tim penyusunan rencana pemekaran Kabupaten Ogan Komering Ulu, dan melalui surat keputusan Gubernur Sumatera Selatan Nomor : 670/SK/W/2001 tanggal 13 Februari 2001, dibentuk tim peneliti rencana penetapan Kabupaten dan Kota Administratif 
menjadi Kotamadya dalam Propinsi Sumatera Selatan ${ }^{12}$.

\subsection{Struktur dan Peranan PPP-KOT Dalam Proses Pemekaran Wilayah Oku Timur}

Pada tanggal 15 Agustus 2001 dibentuk panitia pembantu persiapan pemekaran kabupaten OKU Timur dengan ketua H.A. Rasyid Yusuf, dari panitia pembantu itulah ditingkatkan menjadi Panitia Persiapan Pembetukan Kabupaten Ogan Komering Ulu Timur (PPP - KOT), pada tamggal 6 Juli 2002 yang di ketuai oleh Drs. Syahrir Oesman yang tugasnya antara lain memepersiapkan segala sarana dan prasarana yag diperlukan sebagai daerah pemekaran baru, seperti lahan utuk perkantoran dan perkantoran setelah kabupaten OKU Timur terbentuk ${ }^{13}$.

Panitia pembantu ini kemudian pada tanggal 6 Juli 2002 ditingkatkan menjadi Panitia Persiapan Pemebntukan Kabupaten Ogan Komering Ulu Timur (yang disingkat PPP-KOT) diketuai oleh Drs. Syahrir Oesman yang tugasnya antara lain mempersiapkan sarana dan prasarana, seperti lahan untuk perkantoran dan hal-hal yang diperlukan.Namun dalam kurun waktu 2 (dua) tahun rencana pemekaran Kabupaten Ogan Komering Ulu belum menunjukkan kepastian, sehingga seluruh elemen masyarakat termasuk Panitia Persiapan Pembentukan Kabuapten Ogan Komering Ulu Timur (PPP-KOT) menyampaikan aspirasi secara terbuka di lapangan Ahmad Yani Baturaja.

\subsection{Daftar Ketua dan susunan Pemimpin} pada periode transisi PPP-KOT

\begin{tabular}{|c|c|c|}
\hline Nama Elit & Jabatan & Tahun \\
\hline H.A. Rasyid & Panitia & 2001 \\
Yusuf, & pembantu & \\
& persiapan & \\
& pemekaran & \\
& kabupaten & \\
& OKU Timur & \\
\hline
\end{tabular}

\begin{tabular}{|c|c|c|}
\hline $\begin{array}{c}\text { Drs. Syahrir } \\
\text { Oesman }\end{array}$ & $\begin{array}{c}\text { Panitia } \\
\text { Persiapan } \\
\text { Pembetukan } \\
\text { Kabupaten } \\
\text { Ogan } \\
\text { Komering } \\
\text { Ulu Timur } \\
\text { (PPP - KOT) }\end{array}$ & 2002 \\
\hline $\begin{array}{c}\text { Drs. Amri } \\
\text { Iskandar,MM }\end{array}$ & $\begin{array}{l}\text { PLT Bupati } \\
\text { Ogan } \\
\text { Komering } \\
\text { Ulu Timur }\end{array}$ & 2004 \\
\hline Drs.Sujiadi,MM & $\begin{array}{c}\text { PLT Bupati } \\
\text { Ogan } \\
\text { Komering } \\
\text { Ulu Timur }\end{array}$ & 2004 \\
\hline
\end{tabular}

Dinilai suasana belum menentu, maka PPP - KOT mengajak seluruh elemen masyarakat untuk mengajak melakukan aksi di lapangan A.Yani di Baturaja secara tertib dan aksi ini membawa dampak yang positif, yaitu dengan adanya dukungan DPRD Propinsi Sumatera Selatan dengan surat keputusan Nomor 10 Tahun 2002 tanggal 23 Agustus 2002 memberikan persetujuan terhadap pemekaran kabupaten Ogan Komering Ulu menjadi 3 (tiga) kabupaten. DPR-RI melalui komisi II melakukan kunjugan ke daerah pemekaran. Puncak dari perjuangan PPP - KOT dan seluruh elemen masyarakat telah membuahkan hasil, yaitu dikukuhkannya pemekaran dengan dikeuarkannya undang - undang Nomor 37 Tahun 2003 tanggal 18 Desember 2003, dan kemudian Gubernur Sumatera Selatan melantik pejabat semetara Bupati Ogan Komering Ulu Timur Tanggal 17 Januari 20012004 di Martapura sebagai Ibu kota kabupaten OKU Timur berdasarkan perda Nomor 30 Tahun 2007 tanggal 27 Agustus 200714.

Tanggal 17 Januari 2004 Gubernur Sumatera Selatan melantik Drs. Amri Iskandar,MM sebagai pejabat Bupati Ogan Komering Ulu Timur dan telah meletakkan kerangka awal dari penataan kelembagaan dan dimulai jalannya roda Pemerintahan Kabupaten Ogan Komering 
Ulu Timur yang dilanjutkan oleh Drs.Sujiadi,MM sebagai pejabat Bupati sampai dengan dilantiknya Bupati Ogan Komering Ulu Timur yang definitif.

Pejabat sementara Bupati Ogan Komering Ulu Timur Drs. Sujiadi yang menjabat sementara pada tanggal 25 Februari 2005 - 23 Agustus 2005. Pejabat sementara ini membentuk pemerintahan OKU Timur dan melaksanakan pemilu pada 5 juli tahun 2005 dibawah koordinasi KPUD, Pasangan H. Herman Deru, SH dan HM Kholid Mawardi terpilih menjadi Bupati dan Wakil Bupati Defenitif OKU TIMUR yang pertama yaitu menjabat pada tanggal 23 Agustus 2005 hingga sekarang. Pelantikan Bupati dan wakil ini dilakukan pada tanggal 23 Agustus 200515.

Sebelum menjadi seorang Bupati nama Herman deru telah dikenal Dikalangan dunia bisnis Sumatera Selatan, nama Herman Deru bukanlah sosok yang asing, beliau dikenal sebagai seorang pebisnis dan usaha baik oleh kalangan atas dan bawah. Beliau sangat dekat dengan kalangan menengah ke bawah, tidak heran jika pada saat pemilihan definitif pertama Kabupaten OKU Timur Herman Deru dan HM Kholid Mawardi menang telak dari calon pasangan Bupati lainnya, apalagi pemilihan tersebut bukan lagi dilakukan oleh orang yang duduk di Lembaga legilatif (DPRD) melainkan lewat pemilihan langsung.

Hal ini sebenarnya tidaklah mengherankan karena Herman Deru merupakan Putra daerah asli OKU Timur, Herman Deru lahir di Desa Sidomulyo Belitang. Hal ini juga salah satu faktor dari kelebihan yang dimiliki oleh elite lokal tentang pengaruh dan juga kekuasannya secara harfiah memang untuk memenangkan pemilhan kepala daerah. Sedangkan pasangnya HM Kholid MD merupakan salah elite politik senior dengan rekam jejak yang telah lama berkecimpung di dunia politik, Staff seksi pengembangan desa dinas PMD Pemkab OKU Tahun, pada tahun 19821983 Kasi PMD Kecamatan Pengandonan
Kabupaten OKU Tahun 1983-1987, Kasi PMD Kecamatan Buay Madang Kabupaten OKU Tahun 1987-1996, Sekcam Kecamatan Buay Madang, Kabupaten OKU Tahun 19961997,Anggota DPRD Kabupaten OKU Tahun 1997-1999, Kasi PUGR PMD Kabupaten OKU Tahun 1999-2001, Camat Madang Suku I Kabupaten OKU Timur Tahun 2001-2005, Wakil Bupati Kabupaten OKU Timur Tahun 2005-2010, Wakil Bupati Kabupaten OKU Timur Priode ke II Tahun 2010-Sekarang 16

Pemekaran Kabupaten Ogan Komering Ulu (OKU) menjadi tiga Kabupaten didukung oleh pernyataan Tokoh Masyarakat, Partai Politik dan seluruh elemen masyarakat Kabupaten Ogan Komering Ulu. Dalam menyikapi hal itu, pemerintah Kabupaten Ogan Komering Ulu melayangkan surat kepada DPRD dengan Nomor 125/719/I/2001 tanggal 17 Mei 2000 tentang penetapan rencana pemindahan Ibu Kota Kabupaten Ogan Komering Ulu dan surat Bupati Ogan Komering Ulu Nomor 136/II/2001 tanggal 25 Mei 2001 perihal usulan rencana pemekaran Kabupaten Ogan Komering Ulu, kemudian DPRD merespon, melalui surat keputusan DPRD Nomor 33 Tahun 2000 tanggal 13 Juli 2000 mendapat persetujuan terhadap rencana pemekaran wilayah Kabupaten Ogan Komering Ulu. Selanjutnya ditindaklanjuti dengan surat keputusan Bupati Nomor 125/10.A/SK/2001, dengan pembentukkan tim penyusunan rencana pemekaran wilayah Kabupaten Ogan Komering, kemudian disusulkan dengan surat keputusan Nomor 136/1760/2001 tanggal 23 Oktober 2001 tentang permohonan persetujuan dukungan anggaran dari pemerintah dan surat keputusan Nomor 136/818/SK/I/2001 tanggal 27 Nopember 2001 tentang dukungan dana awal untuk Kabupaten Pemekaran.

Menyikapi hal ini DPRD dengan keputusan Nomor 37 Tahun 2001 tanggal 19 Desember 2001 memberikan persetujuan terhadap rencana dukungan 
dana yang akan dibantu melalui APBD. Demikian pula dukungan Gubernur Sumatera Selatan dengan surat keputusan Nomor 670/SK/W/2001 tanggal 13 Februari 2001, membentuk tim peneliti rencana penetapan Kabupaten dan Kota Administratif menjadi Kotamadya dalam Propinsi Sumatera Selatan. Namun demikian, dalam kurun waktu akhir 2 (dua) Tahun suasana belum menentu, PPP - KOT beserta seluruh elemen masyarakat termasuk PPP - KOST mengambil sikap untuk melakukan aksi damai di lapangan A. Yani Baturaja dan aksi damai ini ternyata membawa dampak yang positif, yaitu dengan adanya dukungan DPRD Propinsi Sumatera Selatan dengan surat keputusan Nomor 10 Tahun 2002 tanggal 23 Agustus 2002 memberikan persetujuan terhadap pemekaran Kabupaten Ogan Komering Ulu menjadi 3 (tiga) Kabupaten ${ }^{17}$.Terlihat dengan jelas disini peranan elit politik lokal dalam proses pemekaran yang terdapat di Oku Timur. Secara umum mereka yang mengusahakan adanya pelaksanaan otonomi daerah ini atas nama warga Oku Timur sendiri.

Pada Awalnya di wilayah OKU Timur terdapat 10 Kecamatan yang nantinya akan menjadi cikal bakal dan terlibat dalam pemekaran Kabupaten OKU Timur diantaranya, Kecamatan Bungamayang, Jayapura, BP Peliung, BP Bangsaraja, Madangsuku I, Madangsuku, III, Cempaka, dan Kecamatan Semendawai Barat,Belitang dan Martapura. Dari beberapa kecamatan inilah nantinya akan bermunuculan para elit-elit lokal yang memberi pengaruh pada PPP-KOT (wawancara dengan bapak Badri , 11September 2018, tokoh masyarakat OKU Timur)

Perananan elit politik lokal dalam pemekaran OKU timur ini dimulai dari gerakan beberapa para anggota partai dan kepala desa yang menjabat di daerah OKU pada saat itu yang saat ini sudah menjadi OKU Timur, adapun beberapa nama dari para kepala desa yang ikut serta dalam PPP-KOT adalah;

Tabel. 3.2 Daftar Kepala Desa Yang ikut dalam PPP-KOT

\begin{tabular}{|c|c|c|c|}
\hline $\begin{array}{l}\mathrm{N} \\
\mathrm{O}\end{array}$ & Nama & $\begin{array}{c}\text { Kepala } \\
\text { Desa }\end{array}$ & $\begin{array}{c}\text { Keanggotaa } \\
\text { n Partai }\end{array}$ \\
\hline 1 & Khaidir & Peracak & - \\
\hline 2 & $\begin{array}{l}\text { Abdullah } \\
\text { Agus Cik }\end{array}$ & $\begin{array}{c}\text { Negeri } \\
\text { Ratu }\end{array}$ & PPP \\
\hline 3 & Mukhlisin & $\begin{array}{l}\text { Sabah } \\
\text { lioh }\end{array}$ & Golkar \\
\hline 4 & $\begin{array}{l}\text { H Abdul } \\
\text { Romli }\end{array}$ & $\begin{array}{l}\text { Tulang } \\
\text { Bawang }\end{array}$ & PAN \\
\hline 5 & $\begin{array}{l}\text { Basyarudi } \\
\mathrm{n}\end{array}$ & $\begin{array}{l}\text { Baturaja } \\
\text { Bungin }\end{array}$ & - \\
\hline 6 & $\begin{array}{l}\text { Abdul } \\
\text { Manan }\end{array}$ & $\begin{array}{l}\text { Jayapura } \\
\text { /Lengot }\end{array}$ & PPP \\
\hline 7 & Lukman & $\begin{array}{l}\text { Kota } \\
\text { Baru }\end{array}$ & - \\
\hline 8 & Junaidi & Praja & - \\
\hline 9 & Zulkaman & $\begin{array}{l}\text { Tanjung } \\
\text { kemala }\end{array}$ & Golkar \\
\hline 10 & $\begin{array}{l}\text { Adi } \\
\text { Winarto }\end{array}$ & $\begin{array}{c}\text { Saung } \\
\text { dadi }\end{array}$ & - \\
\hline 11 & Herman & $\begin{array}{l}\text { Pemetun } \\
\text { g Basuki }\end{array}$ & PDI \\
\hline 12 & Sarofi & Bantah & PDI \\
\hline
\end{tabular}

(wawancara, Muhammad Fikri, 11

September 2018, Anggota Partai PAN dan Mantan Kades Desa Sabah lioh).

Beberapa Alasan atas tuntutan para elit politik lokal ini mengapa harus segera daerah OKU timur ini di mekerkan karena atas dasar percepatan pembangunan dearah dan mempermudah akses masyarakat, karena selama ini para masyarakat OKU pada saat itu untuk mengurus masalah adminitrasi mereka haruslah datang berpuluh-puluh kilo meter ke Baturaja (Saat ini adalah OKU Induk). Selain itu juga selama ini OKU Timur dikenal sebagai penghasil beras atau merupakan salah satu lumbung pangan Sumsel, dengan alasan ini tentu saja tidak ada alasan untuk OKU Timur tidak berkembang dengan cepat (wawancara dengan bapak Badri, tokoh masyarakat OKU Timur) 
Setelah orasi para elit politik lokal ini pada aksi damai di lapangan A. Yani Baturaja untuk menuntut ada terjadinya pemekaran, pada teori sebelumya dikatakan bahwa setelah terjadinya pemekeran para elit politik lokal ini akan menjadi penguasa di dearah ini ternyata bisa dikatakan salah. Atas jasa mereka pada PPP-KOT yang memperjuangkan hak otonomi OKU Timur. Walaupun jika mereka ingin meminta jabatan di pemerintahan daerah sebagai wakil anggota dewan hal itu tidaklah mereka lakukan, kalaupun ada dari beberapa daftar kepala desa yang telah disebutkan tadi hanya dua yang menjadi anggota dewan daerah dan itu pun melalui proses pemilihan umum ${ }^{18}$.

Melihat bagaimana kekuatan atau bagaiaman peran dari para elit politik lokal ini tidak dapat di pisahkan dari teori Strukturasi, sebagaimana diungkapkan Giddens, selain dapat membatasi (constraining) dapat pula memberdayakan (enabling) pelaku (agency). Dikarenakan struktur dimaknai sebagai aturan (rules) dan sumber daya (resources), maka struktur dapat 'diatur' atau 'dikendalikan' oleh negara. Adapun artinya, negara (dalam hal ini pemerintah) dengan kewenangan yang dimilikinya dapat menjadikan struktur sebagai sesuatu hal yang membatasi atau memberdayakan pelaku. Apabila negara dengan kewenangannya dapat 'mengatur' atau 'mengendalikan' struktur, maka elit politik lokal diposisikan sebagai pelaku atau 'agency' yang keberadaannya dipengaruhi oleh struktur. Struktur dinyatakan membatasi elit politik lokal, apabila negara bertindak sedemikian rupa sehingga aturan dan sumber daya yang ada akan membatasi atau mengekang ruang gerak elit politik lokal. Sebaliknya, struktur dinyatakan memberdayakan elit politik lokal, apabila aturan dan sumber daya yang dikendalikan negara membuka peluang atau memberdayakan elit politik lokal untuk memperoleh kemudahan atau keuntungan bagi dirinya.
Dalam konteks hubungannya dengan elit politik lokal sebagai pelaku, tindakan yang dilakukan negara dalam mengendalikan struktur sangat mungkin akan menjadikan struktur tersebut membatasi atau mengekang bagi elit politik lokal dari etnis tertentu, namun tindakan yang sama akan menjadikan struktur cenderung memberdayakan bagi elit politik lokal dari etnis yang lainnya. Hal ini dimungkinkan karena 'constraining' ataupun 'enabling'-nya struktur bagi 'agency' dipengaruhi pula oleh kondisi dan kepentingan pelaku. Sebagai ilustrasi dalam sistem politik yang bercorak otoritarian sentralistis, wacana sentralisasi dan stabilitas (gugus struktur signifikasi), kuatnya kontrol pemerintah pusat dalam pembuatan dan pelaksanaan ${ }^{19}$.

Sebagai ilustrasi dalam sistem politik yang bercorak otoritarian sentralistis, wacana sentralisasi dan stabilitas (gugus struktur signifikasi), kuatnya kontrol pemerintah pusat dalam pembuatan dan pelaksanaan kebijakan (gugus struktur dominasi), dan keleluasaan pemerintah pusat memberi 'reward' dan 'sanksi' (gugus struktur legitimasi) kesemuanya dapat dikendalikan oleh negara; ternyata ketiga gugus struktur tersebut dapat dimaknai sebagai pembatasan atau pengekangan oleh elit politik lokal dari etnis tertentu, tetapi dapat pula dimaknai sebagai pemberdayaan bagi elit politik lokal dari etnis yang lainnya.

Melanjutkan ilustrasi di atas, sebagai contoh, elit politik lokal tertentu yang berasal dari etnis kecil tetapi mempunyai kemampuan atau kapasitas unggul, akan cenderung memaknai struktur yang ada relatif memberdayakan mereka. Adapun alasannya karena negara dengan pemerintahan yang bercorak otoritarian sentralistis dan menekankan pada stabilitas akan lebih mempertimbangkan kemampuan atau kapasitas mereka, dan hal ini jelas memberi keuntungan atau peluang bagi elit politik lokal dari etnis kecil tetapi 
berkemampuan. Sementara itu, ilustrasi tersebut dimaknai bahwa struktur yang ada relatif mengekang atau membatasi bagi elit politik lokal yang tidak mempunyai kemampuan atau kapasitas yang memadai walaupun mereka berasal dari etnis besar.

Struktur yang dimaknai sebagai aturan dan sumber daya dapat mempengaruhi elit politik lokal sebagai pelaku dalam bentuk pembatasan ataupun pemberdayaan; namun di sisi lain elit politik lokal dengan kreativitas yang dimilikinya dapat menyiasati sebagai upaya mempengaruhi struktur yang ada. Hal ini selaras dengan pernyataan Giddens di atas bahwa hubungan antara pelaku dengan struktur bersifat dualitas atau timbal balik. Persoalannya adalah terletak pada elit politik lokal itu sendiri, apakah yang bersangkutan mampu atau tidak menciptakan kreativitas guna menyiasati struktur yang ada. Berkaitan dengan adanya peluang bagi pelaku untuk menyiasati struktur, maka elit politik lokal dalam posisinya sebagai pelaku harus mampu memanfaatkan segenap potensi yang dipunyai dan mempertimbangkan kondisi ligkungan yang melingkupinya. Perubahan yang terjadi pada sistem politik, misalnya dari otoritarian sentralistis menjadi demokrasi .

Berdasarkan dari beberapa hasil data dan analisis yang didapatkan di lapangan maka peneliti melihat bahwa hal yang dilakukan semata-mata bagaiamana para elit politik lokal yang tersebut untuk kepentingan masyarakat banyak tanpa mementingkan kepentingan pribadi mereka, dan juga untuk memanfaatkan potensi lokal yang ada di OKU timur serta atas azas cinta dengan tanah nenek moyang mereka yang merupakan identitas mereka.

\section{Kesimpulan}

Elit politik daerah yang berperan dalam pemekaran Kabupaten OKU Timur adalah para kepala desa, tokoh masyarakat dan para anggota partai nasional yang terdiri dari para penduduk lokal, Beberapa alasan kenapa terjadinya pemekaran daerah di Kabupaten OKU Timur adalah masalah akses adminitrasi publik yang sulit dan bagaiamana masyarakat dalam menjalankan kehidupan sehari-hari, karena selama ini masyarakat sebelum terbentuknya OKU Timur selalu melakukan aktivitas adminitrasi publik di daerah Baturaja atau Kabupaten OKU Induk sebagai Pusat dari Kabupaten OKU, yang menjadi kendala adalah jarak tempuh kedua daerah yang cukup jauh.

Persepsi yang salah apabila dikatakan para elit politik lokal ini mengambil keuntungan dari pemekaran daerah OKU Timur, karena alasan mereka semata-mata untuk turut serta dalam memperjuangkan kemajuan daerah mereka, secara teori mereka akan mendapatkan jatah dalam kursi kepemimpinan daerah atas jasa mereka dalam usaha pemekeran yang telah berhasil ini, namun pada kenyataannya hanya beberapa saja dari para kepala desa dan para elit dari beberapa partai yang turut serta dalam PPP-KOT ini yang menjadi anggota dewan, karena mereka harus ikut dalam pemilu legislatif terlebih dahulu tanpa melalui jalan pintas.

\section{Referensi}

1 Widjaja, H.A.W (1998). Percontohan Otonomi Daerah Di Indonesia. Jakarta : Penerbit Rineka Cipta. Hlm 148.

${ }^{2}$ Bratakusumah, Deddy Supriadi, Ph.D dan Dadang Solihin, MA. (2001). OtonomiPenyelenggaraan Pemerintah Daerah. . Jakarta : PT. Gramedia Pustaka Utama. Hlm 6.

3 Widjaja, H.A.W (1998). Percontohan Otonomi Daerah Di Indonesia. Jakarta : Penerbit Rineka Cipta.HIm 10. 
4 Haryanto,2009. Elit Politik Lokal Dalam Perubahan Sistem Politik, Jurnal Ilmu Sosial Dan Ilmu Politik, Vol. 13, Nomor 2, November 2009

5 Zuhdi, Susanto. (2014). Nasionalisme, Laut, Dan Sejarah. Depok : Komunitas Bambu. hlm 7.

6 S. Priyadi,2012. Metode Penelitian Pendidikan Sejarah. Yogyakarta: Penerbit Ombak,

7 S. Kartodirjo,1993. Pendekatan Ilmu Sosial Dalam Metodologi Sejarah. Jakarta: PT. Gramedia Pustaka Umum.,

8 Ratnawati, T. (2010). Satu Dasa Warsa Pemekaran Daerah Era Reformasi: Kegagalan Otonomi Daerah. Jurnal Ilmu Politik, Edisi, 21, 122-235.

9 Alexander Abe, 2001. Perencanaan Daerah Memperkuat Prakarsa Rakyat Dalam Otonomi Daerah. Lapera Pustaka Utama, Yogyakarta.

${ }^{10}$ Agustino, L., \& Yusoff, M. A. (2010). Politik Lokal Di Indonesia: Dari Otokratik Ke Reformasi Politik. Jurnal Ilmu Politik, Edisi, 21, 2010

11 Kansil, C.C.T, Dkk. 2008. Pemerintah Daerah Di Indonesia. Jakarta: Pt Sinar Gerafika. Hlm 362

12 (www.okutimurkab.go.id.diakses pada 11 September 2018)

${ }^{13}$ (Wawancara, 11 September 2018, bapak Yusfik Fatih Kades Kotabaru Barat, )

${ }^{14}$ (Wawancara, 11September 2018 bapak Yusfik Patih Kepala Desa Kotabaru Barat)

15 Imron,Rustam. 2006. Pokok-Pokok Pikiran Pembangunan OKU Timur, Memantapkan Kemandirian. Martapura: CV. SP Jaya. Hlm 3-4.
16 (wawancara, Muhammad Fikri, 11 September 2018, Anggota Partai PAN dan Mantan Kades Desa Sabah lioh).

17 Website Kementerian Dalam Negeri www.kemendagri.go.id (diakses pada 11 September 2018)

18 (Wawancara, Muhammad Fikri, 11 September 2018, Anggota Partai PAN dan Mantan Kades Desa Sabah lioh)

19 Haryanto,2009. Elit Politik Lokal Dalam Perubahan Sistem Politik, Jurnal Ilmu Sosial Dan Ilmu Politik, Vol. 13, Nomor 2, November 2009 